\title{
The Determinants of Insurance Firm Value with Enterprise Risk Management (ERM) as Intervening Variable
}

\author{
Achmad Achsan Zainul Mafakhir Shaleh ${ }^{1} \&$ Augustina Kurniasih ${ }^{2}$ \\ 1 Student of Master of Management, Faculty of Economics and Business, Mercu Buana University, Jakarta, \\ Indonesia \\ ${ }^{2}$ Lecturer in Master of Management, Faculty of Economics and Business, Mercu Buana University, Jakarta, \\ Indonesia \\ Correspondence: Achmad Achsan Zainul Mafakhir Shaleh, Indonesia. E-mail: achsan_nagata@yahoo.com
}

Received: May 12, 2021 Accepted: May 24, 2021 Online Published: May 26, 2021

\begin{abstract}
This study aims to examine and analyze the ability of the ERM (enterprise risk management) to mediate the influence of the firm size, leverage, profitability, and institutional ownership on the firm value of the insurance sub-sector listed on the Indonesia Stock Exchange for the period 2015-2019. This study used 12 samples from 16 insurance companies listed on the IDX in 2020 that met the criteria for purposive sampling. The data were processed using a path analysis approach. The results of the research show that firm size has a significant positive effect on ERM, DER and ROA has a significant negative effect on ERM, and institutional ownership were found to have no effect on ERM. Meanwhile, DER and institutional ownership have a significant negative effect on firm value, while firm size, ROA and ERM have no effect on firm value. Using the Sobel Test it was found that ERM as intervening variable was unable to mediate the effect of firm size, DER, ROA, institutional ownership on firm value.
\end{abstract}

Keywords: firm value, enterprise risk management (ERM), firm size, DER, ROA, institutional ownership

\section{Introduction}

\subsection{Introduce the Problem}

The current development of economic conditions in Indonesia has created increasingly fierce competition among the financial services industry, where financial service companies are competing with each other to improve their performance and firm value. Businesses without insurance support may find it difficult to continue their business activities, because business risks do not fully have the capacity to store all types of risks in uncertain environmental conditions (Ahmed, et al. 2010). Insurance is needed in mobilizing savings, supporting trade, improving the quality of individual life and overall welfare (Malik, 2011). The main objective of an insurance company listed on the Indonesia Stock Exchange is to increase the prosperity of its stakeholders and shareholders by increasing firm value. According to Harmono (2009), firm value shows the company's performance as reflected by the stock price that is formed from the demand and supply of the capital market as well as a reflection of the public's assessment of the company's performance to maintain and develop its business in providing benefits to its owners. The firm value itself can be proxied by Tobin's Q value which compares the ratio of the company's stock market value to the book value of the company's equity (Hartono, 2000).

The insurance industry in Indonesia in the last five years which was marked by a scandal in the case of default of insurance policy claims, which was created public concern about the insurance industry in Indonesia. As an example of the Jiwasraya Insurance case which was declared to have failed to pay the policy claim of the JS Saving Plan customer in October 2018 amounting to IDR 802 billion \& December 2019 IDR 12.4 trillion. Furthermore, the Bumiputera 1912 Life Insurance case in the first half of 2019 , had an RBC ratio of $-628.4 \%$, an investment adequacy ratio of only $22.4 \%$, and a liquidity ratio of 52.4\%. In 2020, Bumiputera 1912 Insurance has a jumbo claim arrears that must be paid immediately to 365,000 policyholders throughout Indonesia amounting to IDR 5.3 trillion (Hastuti, 2020). These cases have an impact on the value of the insurance sub-sector companies listed on the Indonesia Stock Exchange as shown in Graph 1. 


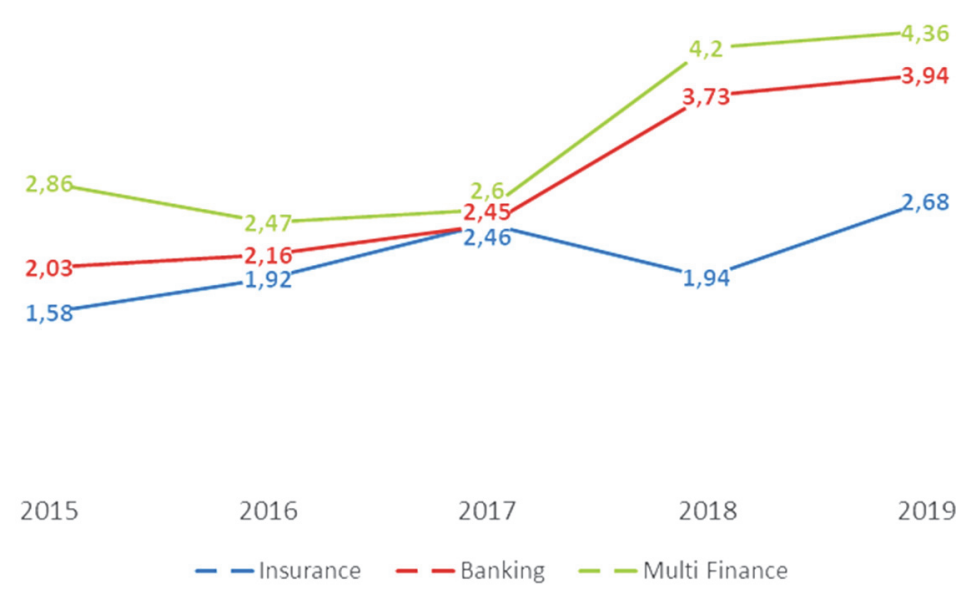

Graph 1. The average value of Tobin's Q

Source: IDX and data processed by the author (2020)

Graph 1 shows that in 2015-2017 the sub-sector insurance experienced an increase in value, but in 2018 the value of company decrease in 0.52 point. On the other hand at the same time, the banking and multi-finance sub-sectors experienced an increase in firm value. One of the efforts to increase firm value is through regular ERM disclosure in the company's annual report (Hoyt and Liebenberg, 2011). Meanwhile, according to Bertinetti (2013) ERM is a value driver in increasing firm value.

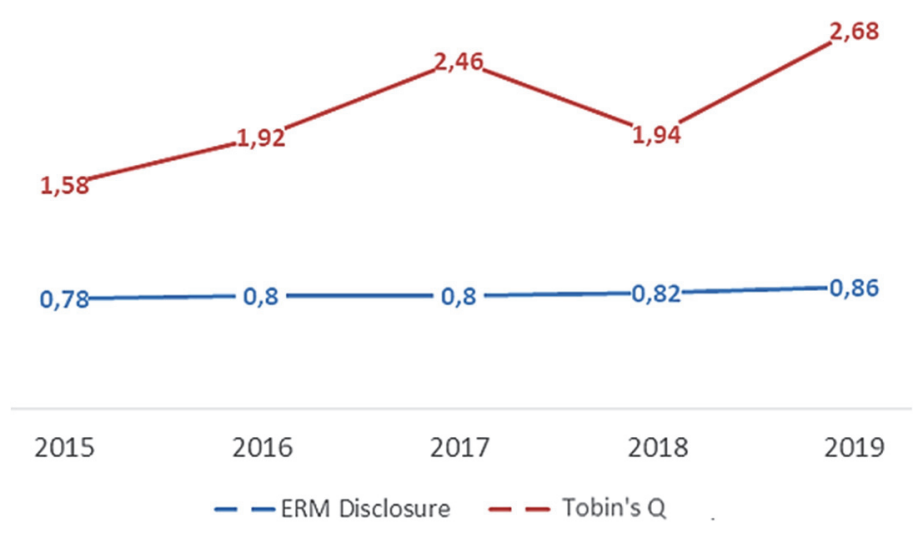

Graph 2. Average value of Tobin's Q \& ERM Disclosure for Insurance Companies

Source: IDX and data processed by the author (2020)

Graph 2 shows that from 2015 to 2017, the value of ERM disclosure in insurance companies tends to increase every year, followed by a positive trend of increasing firm value. According to the Chairperson of AAJI Budi Tampubulon, this period has not yet occurred in public distrust to the insurance industry (Wareza, 2020). Community distrust began to appear in 2018, where there was a decline in firm value even though ERM disclosure increased. Meanwhile, the positive trend of firm value in 2019 occurred due to the disclosure of jiwasraya suspects issue, jiwasraya internal restructuring scheme and a plan to holdingization the state insurance industry by the government of the Republic of Indonesia (Republika, January 2020).

Previous research on the factors that influence firm value and ERM has still found mixed results. Rachmawati (2015) and Husaini (2017) found a significant positive effect firm size on firm value. While Li (2016), Tahir (2011), Farhan (2017) did not find any influence of firm size on firm value. Al-Shammari (2014), Farida (2019), and Onder (2012) found that firm size had a significant positive effect on ERM. Meanwhile, Tahir (2011), Kumalasari (2014), and Sulistyaningsih (2016) found no influence firm size on ERM. 
Regarding firm leverage, Aditya (2017), Pratama (2016), and Abdullah (2015) found a significant positive effect of DER on firm value. Meanwhile Rahma (2014), Suteja (2009) found a significant negative effect of DER on firm value. The results of Saskara (2018) and Kumalasari (2014) found a significant positive effect of DER on ERM. Research Syifa (2013), Tahir (2011), and Pristianingrum (2018) did not find the effect of DER on ERM. Meanwhile, Tessema (2016) and Marhaeni (2015) found a significant negative effect of DER on ERM.

Research by Bertinetti (2013), Agustina (2016), and Endri (2020) found a significant positive effect of ROA on firm value. Meanwhile, Farhan (2017) and Lin (2016) did not find any effect of ROA on firm value. The research of Saskara (2018) and Kumalasari (2014) found a significant positive effect of ROA on ERM. Meanwhile, the research of Onder (2012), Al-Shammari (2014), and Tahir (2011) did not find any effect of ROA on ERM. The research results of Wimelda (2017), Ratnawati (2018), Purba (2019) found a significant positive effect of institutional ownership on firm value. Research by Nuraina (2012) did not find any effect of institutional ownership on firm value. Meanwhile Rahma (2014), Suteja (2009) found a significant negative effect of institutional ownership on firm value. Research by Rujiin (2020) found a significant negative effect of institutional ownership on ERM (2018), Pristianingrum (2018), \& Lestari (2017) has proven that institutional ownership has a significant positive effect on ERM.

Taking into the background and the results of previous studies, the author suspect firm size, DER, ROA, and institutional ownership can influence ERM disclosure which will have an impact on increasing firm value. ERM encourages management to act effectively and efficiently in dealing with uncertain environmental conditions related to business risks and opportunities, and can increase its capacity to increase firm value (COSO, 2004). Research by Li (2016), Husaini (2017), Iswajuni (2018) found that there was a significant positive effect of ERM on firm value. Meanwhile, the results of Aditya (2017), Abdullah (2015), \& Lin (2016) did not find any effect of ERM on firm value.

In Indonesia, the importance of risk management in non-bank financial companies has been regulated by the OJK (Financial Services Authority) through Regulation number 1 / POJK.05 / 2015 which requires Non-Bank Financial Services Institutions (LJKNB) to form a Risk Management Committee (OJK, 2015 ), so that it can be ascertained that all Non-Bank Financial Services companies operating in Indonesia have a Risk Management Committee in it.

Based on the phenomena of problems and research gaps above, this study aims to analyze the effect of firm size, DER, ROA, institutional ownership and ERM on firm value by making ERM a mediating variable. The study was conducted on insurance companies listed on the Indonesia Stock Exchange with an observation from 2015 to 2019.

\subsection{Theoretical Background}

\subsubsection{Agency Theory}

Jensen (1976) in Agency Theory views that managers and shareholders have different interests in running the company's business. Company managers are hired hands who are believed to be more interested in efforts to improve personal welfare than shareholder, this can be a conflict of interest between the principal \& agent.

\subsubsection{Trade-Off Theory}

Trade-Off Theory was introduced by Modigani and Miller in 1958. This theory states that there is a need to balance the benefits and sacrifices that arise as a result of the use of debt. As long as the benefits was obtained from debt are greater, additional debt is still permitted. However, when the sacrifices due to the use of debt are getting higher, the additional debt is not allowed.

\subsubsection{Signaling Theory}

The signal theory developed by Ross (1970) is based on the asymmetry theory which states that parties related to publicly traded companies do not have balanced information about the opportunities and risks faced by the company. Company management usually has more complete information on the company's prospects compared to shareholders or investors. Investors who lack information will always interpret company management policies as a certain signal (Mamduh, 2014).

\subsubsection{Firm Value}

Firm Value can be interpreted as a market value that will provide maximum prosperity for investors when the company's stock price rises. Positive policies need to be implemented by company management to increase firm value and the prosperity of shareholders (Brigham, 2014). This is in accordance with the opinion of Salvatore (2005), namely the main objective of the company in the theory of the firm is to prosper the wealth of shareholders. According to Sudana (2011), the valuation ratio of a company can be calculated using three approaches, namely PER (price earning ratio), PBV (price to book value), and Q (Tobin's Q). Tobins' Q is the ratio of the capital market 
value to cost replacement and summarizes all company investment opportunities (Tobin's, 1967). According to Sianturi (2015), Tobins'Q has an advantage because it provides information by comparing the stock market value and the replacement value of company assets, and includes all company assets, share capital and debt.

$$
\text { Tobin's } Q(\mathrm{Q})=\frac{\text { Market Value of Equity + Liability }}{\text { Total Assets }} \quad \mathrm{X} 100 \%
$$

\subsubsection{Enterprise Risk Management}

The classic story of the Roman poet Juvenal depicts The Black Swan as a symbol of an unlikely event (Taleb, 2007). The Black Swan itself has had a major influence on risk management, one of which is financial risk management, which began to develop internal risk management models and calculation formulas to hedge the company against unexpected risks (Dionne, 2013). Initially, risk management was known as Traditional Risk Management (TRM). One of the characteristics of risk management is that each business unit only handles its own risks based on their respective expertise (Butterfield, 2017). Currently this approach has changed to a more comprehensive approach to create risk management that covers all aspects and is implemented in an integrated manner or commonly known as Enterprise Risk Management (Aditya, 2017). According to the Committee of Sponsoring Organizations of the Treadway Commission (2004), ERM is a process that is influenced by the board of directors, management, and other personnel that is carried out in determining strategy and covers all parts of the organization to identify events or risks that can affect, as well as guarantees that reasonable in achieving company goals. COSO (2004) issued the ERM Framework which includes 108 items in 8 dimensions that need to be disclosed in a company's annual report. These dimensions are: 1) internal environment; 2) goal setting; 3) incident identification; 4) risk assessment; 5) response to risk; 6) monitoring activities; 7) information \& communication; 8) monitoring of ERM performance. The measurement of ERM is based on the total items disclosed by a company compared to the total items disclosed by ERM which amounted to 108 .

$$
\text { ERM Disclosure }(\mathrm{ERM})=\frac{\text { Total Items Revealed }}{108} \quad \mathrm{X} 100 \%
$$

\subsubsection{Firm Size}

In the concept of economies of scale, firm size reflects the phenomenon of decreasing production costs per unit in a company accompanied by an increase in production volume. The larger the size of a company, the lower the production cost per unit of product to be produced. On the other hand, a large company will have a greater risk. Large-scale companies tend to have good share value, because many investors are confident about investing their capital in these companies (Kenton, 2020). Firm size is an assessment of how big or small the size of a company is represented by total assets (Benyamin \& Endri, 2019).

$$
\text { Firm Size }=\text { Ln Total Assets }
$$

\subsubsection{Leverage}

Leverage describes how much the company's assets are funded by debt. This ratio illustrates the ability of a company to pay all of its obligations, both short and long term liabilities if a company is liquidated (Kasmir 2015). The high level of leverage reflects that the company's capital structure is more financed by debt than with total equity, so that this can create financial risks for the company if it is not managed properly. Companies with high leverage levels usually tend to disclose low ERM processes to stakeholders, so that they can continue to attract investors to investing in their companies (Rujiin, 2020). The leverage ratio is often calculated using the DER ratio.

$$
\text { Debt to Equity Ratio }(\mathrm{DER})=\frac{\text { Total Debt }}{\text { Total Equity }} \times 100 \%
$$

\subsubsection{Profitability}

Profitability shows the ability of a company to generate net income. According to Sofyan (2011) profitability describes a company's ability to benefit from various existing resources such as capital, sales, cash, number of branches, number of employees, and others. Kasmir (2015) states that profitability is the company's ability to achieve maximum profit and is a measure of the effectiveness of company management. Companies that have high profits will find easy funding and trust from investors to increase their firm value. One measure of profitability is the ROA ratio.

$$
\text { Return on Assets }(\mathrm{ROA})=\frac{\text { Net Profit }}{\text { Total Asset }} \quad \mathrm{X} 100 \%
$$




\subsubsection{Institutional Ownership}

According to Nuraina (2012), institutional ownership is the total percentage of company shares owned by institutions such as insurance companies, pension fund management institutions, banking, investment, foundations, and other institutions. The existence of shares owned by a local or international institution is considered capable of being an important external control mechanism to increase firm value. The strategic alignment hypothesis (McCardle, 2019) stated if the external supervision is too large, its can turn out to be passive and opportunistic. Institutional investors have a large voting effect to influence management or even force decisions in accordance with their interests and ignore minority shareholdings (Rahma, 2014).

$$
\text { Institutional Ownership (INS) }=\frac{\text { Number of Institutional Shares }}{\text { Number of Outstanding Shares }} \quad \mathrm{X} 100 \%
$$

\subsection{Hyphothesis}

\subsubsection{The Effect of Firm Size on ERM}

The bigger the size of a company, the greater the risks and conflicts of interest between management and shareholders that will be faced, so the company needs to regularly disclose its ERM management. Large companies have strong demands to maintain their reputation in order to gain the trust of investors and stakeholders (Syifa, 2013). Research by Ardiansyah (2014) and Sari (2013) proves that firm size has a significant positive effect on ERM. Based on this description, a hypothesis can be drawn:

$$
\mathrm{H}_{1} \text { : Firm size has a positive effect on ERM }
$$

\subsubsection{The Effect of DER on ERM}

DER as a measure of leverage illustrates the relationship between total debt owed by creditors and company equity. In agency theory, the bigger company's debt will encourage managers to downplay and cover the company's risk by making less ERM disclosures in order to attract investors trust to keep investing in their companies (Rujiin, 2020). The results of research by Tessema (2016) and Marhaeni (2015) prove that leverage has a significant negative effect on ERM. Based on this description, a hypothesis can be drawn:

$$
\mathrm{H}_{2} \text { : DER has a negative effect on ERM. }
$$

\subsubsection{The Effect of ROA on ERM}

ROA is a ratio to measure the level of profitability of a company. The higher ROA was generated, the greater company's responsibility for managing the risk. Companies with high ROA ratios indicate that the company's risk management is done well. The research of Faisal (2020), Saskara (2018), and Kumalasari (2014), proves the significant positive effect of ROA on ERM. Based on this description, a hypothesis can be drawn:

\section{$\mathrm{H}_{3}$ : ROA has a positive effect on ERM.}

\subsubsection{The Effect of Institutional Ownership on ERM}

The institutional ownership is number of shares from outside the company that can be considerable influence on the risk management of a company. The larger shares owned by the institution, the greater ERM information required by institutional investors. Research by Prayoga (2018), Pristianingrum (2018), and Lestari (2017) has proven that institutional ownership has a significant positive effect on ERM. Based on this description, a hypothesis can be drawn:

$$
\mathrm{H}_{4} \text { : Institutional ownership has a positive effect on ERM. }
$$

\subsubsection{The Effect of Firm Size on Firm Value}

The bigger the size of a company, the greater the ease of the company in obtaining funding that can be used by management to increase firm value. The findings of Abdullah (2015), Aditya (2017), Murtini (2018) prove that firm size has a significant positive effect on firm value. Based on this description, a hypothesis can be drawn:

$$
\mathrm{H}_{5} \text { : Firm size has a positive effect on Firm Value. }
$$

\subsubsection{The Effect of DER on Firm Value}

According to signaling theory by Ross (1977), the higher the debt of a company can create a bad signal to investor which is the use of high corporate debt will reduce corporate profits and reduce dividends that investors will receive. The research results of Darmayanti (2018), Farhan (2017) prove that debt has a significant negative effect on firm value. Based on this description, a hypothesis can be drawn: 


\section{$\mathrm{H}_{6}$ : DER has a negative effect on Firm Value}

\subsubsection{The Effect of ROA on Firm Value}

The companies with high ROA provide positive signals for investors to invest their fund. The high ROA value of a company indicates good internal management in increasing firm value. The results of research by Hao (2018), Rachmawati (2015), McShane (2011) prove a significant positive effect of ROA on firm value. Based on this description, a hypothesis can be drawn:

\section{$\mathrm{H}_{7}$ : ROA has a positive effect on Firm Value.}

\subsubsection{The Effect of Institutional Ownership on Firm Value}

The institutional share ownership have a great influence or can force management to make decisions in accordance with their interests and ignore minority shareholdings. The results of research by Rahma (2014), Suteja (2009) prove that institutional ownership has a significant negative effect on firm value. a hypothesis can be drawn:

\section{$\mathrm{H}_{8}$ : Institutional ownership has a negative effect on Firm Value}

\subsubsection{The Effect of Enterprise Risk Management in Firm Value}

Companies that consistently disclose ERM can provide a sense of security and comfort for investors who will invest and will increase firm value. The findings of Pamungkas (2019), Iswajuni (2018), and Husaini (2017) prove a significant positive effect of ERM on firm value. Based on this description, a hypothesis can be drawn:

$\mathrm{H}_{9}$ : ERM has a positive effect on Firm Value.

Based on the description of the hypothesis, below is a research model in this study;

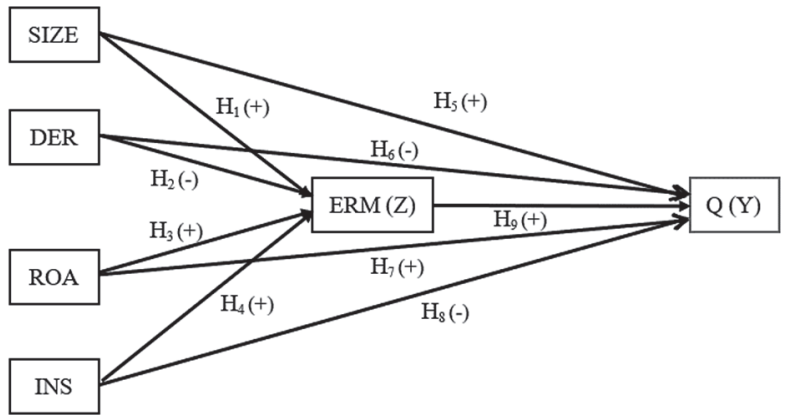

Figure 1. Research Model

\section{Method}

This research is a causality study which aims to prove the effect of independent variables on the dependent variable. The study population was 16 insurance companies listed on the IDX in 2020. Using a purposive sampling technique, it was found that 12 companies met the criteria. The research period is five years (2015-2019). Thus this study uses 60 annual company financial reports. The data analysis method used is path analysis. To determine the significance of the indirect effect of the mediating variables in the model, the Sobel test is used (Ghozali, 2013). The path-1 equation shows the effect of firm size, DER, ROA, institutional ownership on ERM (intervening variable, Z). The path-2 equation shows the effect of firm size, DER, ROA, institutional ownership, ERM on firm value (dependent variable, $\mathrm{Y}$ ).

$$
\begin{aligned}
& \mathrm{ERM}=\mathrm{pZ}_{1} \mathrm{SIZE}+\mathrm{pZ}{ }_{2} \mathrm{DER}+\mathrm{pZ}_{3} \mathrm{ROA}+\mathrm{pZ} \mathrm{Z}_{4} \mathrm{INS}+\varepsilon 1 \ldots \ldots \ldots \ldots \\
& \mathrm{Q}=\mathrm{py}_{1} \mathrm{SIZE}+\mathrm{py}_{2} \mathrm{DER}+\mathrm{py}_{3} \mathrm{ROA}+\mathrm{py}_{4} \mathrm{INS}+\mathrm{pyERM}+\varepsilon 2 \ldots \ldots
\end{aligned}
$$

\section{Results \& Discussion}

Table 1. Descriptive Statistics

\begin{tabular}{llccccc}
\hline No & Variable & N & MIN & MAX & Mean & Std. Deviation \\
\hline 3.1 & SIZE (IDR million) & 60 & 210,608 & $4,626,630$ & $1,640,830$ & $1,205,049$ \\
3.2 & DER & 60 & 0,16 & 4,93 & 1,58 & 1,04
\end{tabular}




\begin{tabular}{llllccc}
3.3 & ROA & 60 & 0,00 & 0,20 & 0,04 & 0,03 \\
3.4 & INS & 60 & 0,22 & 0,99 & 0,72 & 0,25 \\
3.5 & ERM & 60 & 0,33 & 0,94 & 0,82 & 0,13 \\
3.6 & Q & 60 & 0,26 & 12,25 & 1,69 & 2,11 \\
\hline
\end{tabular}

\subsection{Description of SIZE}

Table 1 shows the average firm size (SIZE) value of an insurance company of IDR 1,640,830 million. Insurance companies on average are categorized as small companies or the equivalent of Book Bank II in the banking industry in Indonesia (having assets below IDR 5 trillion). The insurance company with the smallest SIZE (IDR 210.6 billion) is PT. Victoria Insurance Tbk (VINS) 2015. The insurance company with the highest SIZE (IDR 4.6 trillion) is PT. Asuransi Multi Artha Guna Tbk (AMAG) 2019.

\subsection{Description of DER}

The average DER value of 1.58 reflects that every 100 shares of equity bears 158 shares of debt. In other words, the average insurance company is in unsolvable state. The company with the lowest debt (DER $=0.16)$ is owned by PT. Panin Vest Tbk (PNIN) 2019, while the company with the highest debt $(\mathrm{DER}=4.93)$ was experienced by PT. Asuransi Dayin Mitra (ASDM) Tbk 2015.

\subsection{Description of ROA}

The ROA average value of 0.04 indicates that every 100 billion assets can generate a net profit of IDR 4 . The company that generates the lowest profit from its assets $(\mathrm{ROA}=0.00)$ is owned by PT. Asuransi Jasa Tania Tbk (ASJT) 2019. The company that generates the highest profit from its assets $(\mathrm{ROA}=0.20)$ is PT. Asuransi Harta Aman Pratama Tbk (AHAP) 2019.

\subsection{Description of INS}

The average value of share ownership by institutions (INS) is 0.72 , indicating that on average $72 \%$ of the shares of insurance companies are owned by institutions. The smallest INS value (0.22) is owned by PT. Asuransi Kresna Mitra Tbk (ASMI) 2018 \& the largest INS value (0.99) is owned by PT. Panin Vest Tbk (PNIN) 2017-2019 period.

\subsection{Description of ERM}

The average ERM disclosure value of 0.82 indicates that the average insurance company on the IDX is already good at disclosing its ERM, which is $82 \%$ of the total 108 ERM items that need to be disclosed. The company with the lowest ERM disclosure (0.33) is PT. Asuransi Harta Aman Pratama Tbk (AHAP) 2015 and the company with the highest ERM disclosure (0.94) is PT. Asuransi Dayin Mitra Tbk (ASDM) 2017-2019 and Indonesian Reinsurance Company Tbk (MREI) 2015-2019 period. Both companies have very good ERM disclosures.

\subsection{Description of $Q$}

The average firm value of insurance companies on the IDX is 1.69. This means that the market value of the company is higher than the book value of its equity. The lowest firm value $(\mathrm{Q}=0.26)$ is owned by PT. Panin Vest Tbk (PNIN) in 2016. The highest Q value (12.25) is owned by PT. Asuransi Kresna Mitra Tbk (ASMI) 2019.

Table 2. Regression Test Results of Equation-1

\begin{tabular}{lccl}
\hline Variable & $\begin{array}{c}\text { Standardized } \\
\text { Coefficients }\end{array}$ & $\mathrm{t}_{\text {statistic }}$ & Prob. \\
\hline $\mathrm{H}_{1}$ Firm Size (SIZE) & 0.312 & 2.610 & $0.012^{* *}$ \\
$\mathrm{H}_{2}$ Leverage (DER) & -0.214 & -1.738 & $0.088^{*}$ \\
$\mathrm{H}_{3}$ Profitability (ROA) & -0.212 & -1.772 & $0.082^{*}$ \\
$\mathrm{H}_{4}$ Institutional Ownership (INS) & 0.115 & 0.944 & 0.349 \\
& & & \\
R Square & 0.228 & & \\
Adj-R2 & 0.172 & & \\
F-statistic & 4.066 & & \\
Prob (F-statistic) & $0.006^{*}$ & & \\
\hline
\end{tabular}

Dependent Variable: ERM, ${ }^{*}$ Sig. at $\alpha 10 \%$, ** Sig. at $\alpha 5 \%$ 
Result of Equation-1. Table 2 shows that the equation-1 model is a suitable model. The significance value of the Prob F-statistic test 0.006 is smaller than the alpha significance of $10 \%$. The R square value of Equation- 1 is 0.228 indicating that together firm size, leverage, profitability and institutional ownership are able to explain the variability of ERM disclosure by $22.8 \%$. There are still $77.2 \%$ of the influence of other variables that are not included in this research model.

$H_{1}$ result discussion. The regression coefficient value of the effect of firm size on ERM is 0.312 with a significance of 0.012. It means that firm size has a significant positive effect on ERM. If the insurance company's assets increase by 1 million rupiah, the ERM will increase by 0.312 units. These results in line with agency theory which states that large firm sizes have complex risks and need to implement comprehensive risk management. Furthermore, the large companies are tend to maintain their reputation in the eyes of investors by reducing conflicts of interest and sending positive signals in the form of regular ERM disclosures. The findings of this study are in line with Farida (2019) who examined the insurance sub-sector listed on the Indonesia Stock Exchange for the period 20132017, Sithipolvanichgul (2018) who examined public companies listed on the Thailand and Malaysia Stock Exchanges in 2016, and Al- Shammari (2014) who examined non-financial companies on the Kuwait Stock Exchange in 2012. The results of this study are different from the findings of Sulistyaningsih (2016) who examined the manufacturing sector listed on the Indonesia Stock Exchange for the period 2012-2014, Saputro (2014) who examined in the manufacture sector listed on the IDX in the 2010-2012 period.

$\mathrm{H}_{2}$ result discussion. The regression coefficient value of the effect of DER on ERM is -0.214 with a significance of 0.088 . Using alpha $10 \%$, it is found that leverage has a negative and significant effect on ERM. If the company's debt increases by one unit, the ERM will decrease by 0.214 units. This explains that when company debt increases, it will decrease ERM disclosure. The leverage ratio of insurance companies on average is more than 1, reflecting that on average the insurance company is in unsolvable state. Managers are tend to minimize or cover up ERM disclosures that can provide a positive signals and attract investors to continue investing in their companies. This finding is in line with the results of research by Rujiin (2020) which examined the manufacturing sector listed on the Indonesia Stock Exchange for the period 2013-2017, and does not support the results of Onder's (2012) which examined financial companies listed on the Istanbul Stock Exchange in 2007, and Saskara (2018) who examined companies LQ 45 Index on the IDX in the 2012-2016 period.

$\mathrm{H}_{3}$ result discussion. The regression coefficient value of the effect of ROA on ERM is -0.212 with a significance of 0.082 . Using alpha $10 \%$ it was found that profitability has a negative and significant effect on ERM. If the company's profit increases by one unit, the ERM will decrease by $-0,212$ units. This explains that when the company's ROA decreases, it will increase ERM disclosure. This action was carried out as the company's attempt to convince the market that if there was a decline in profit, the company was properly disclosing the company's risk. On average, the ROA of insurance companies is relatively low $(\mathrm{ROA}=4 \%)$ and it is still below the standard ROA that must be achieved (5.98\%) based on net income divided by total assets (Lukviarman, 2006). The relatively low profitability of the company has prompted management to disclose ERM in more detail with the aim of maintaining investor confidence in the risks faced by the company. The findings of this study contradict with agency theory which states that the higher the company's profit, the wider the ERM will be disclosed to minimize conflicts of interest. This result in line with Rujiin (2020) who examined the manufacture sector listed on the Indonesia Stock Exchange for the period 2013-2017, and does not support Saskara (2018) who examined companies LQ 45 Index on the Indonesia Stock Exchange for the period 2012-2016, Kumalasari (2014) who examined the hotel, restaurant and tourism sectors listed on the Indonesia Stock Exchange in 2010-2012 period, as well as Faisal (2020) who examined the manufacture sector listed on the Indonesia Stock Exchange in 2017.

$\mathbf{H}_{4}$ result discussion. The regression coefficient value for the effect of institutional ownership is 0.115 with a significance of 0.349 . This means that institutional ownership has no effect on ERM. The institution as an insurance company shareholder is not able to encourage company managers to disclose ERM. This finding does not support the signal theory which states that the more abundant stock ownership by an institution is, the higher its ERM disclosure. The results of this study in line with Fathimiyah et al. (2011) who did not find any effect of institutional ownership on ERM. Fathimiyah et al. examined the banking sub-sector listed on the Indonesia Stock Exchange for the period 2008-2010. The result of this study is not in line with Prayoga (2013) who examined the manufacture sector listed on the Indonesia Stock Exchange for the period 2007-2011, and Pristianingrum (2018) who examined the mining sector listed on the Indonesia Stock Exchange 2016-2017 period. 
Table 3. Regression Test Results of Equation-2

\begin{tabular}{lccl}
\hline Variable & $\begin{array}{c}\text { Standardized } \\
\text { Coefficients }\end{array}$ & $\mathrm{t}_{\text {statistic }}$ & Prob. \\
\hline $\mathrm{H}_{1}$ Firm Size (SIZE) & -0.082 & -0.657 & 0.514 \\
$\mathrm{H}_{2}$ Leverage (DER) & -0.266 & -2.123 & $0.038^{* *}$ \\
$\mathrm{H}_{3}$ Profitability (ROA) & 0.002 & 0.012 & 0.990 \\
$\mathrm{H}_{4}$ Institutional Ownership (INS) & -0.497 & -4.094 & $0.000^{* * *}$ \\
$\mathrm{H}_{5}$ Enterprise Risk Management (ERM) & 0.104 & 0.782 & 0.438 \\
& & & \\
R Square & 0.261 & & \\
Adj-R2 & 0.193 & & \\
F-statistic & 3.819 & & \\
Prob (F-statistic) & $0.005^{*}$ & & \\
\hline Dep (rtis & & & \\
\hline
\end{tabular}

Dependent Variable: $\mathrm{Q},{ }^{* *}$ Sig. at $\alpha 5 \%, * *$ Sig. at $\alpha 1 \%$

Result of Equation-2. Table 3 shows the Prob F-statistic significance value of 0.005 (less than the alpha significance of $10 \%$ ). It can be concluded that the regression model equation-2 is a suitable model. The $\mathrm{R}$ square value in equation- 2 of 0.261 shows that together the firm size, leverage, profitability, institutional ownership, ERM are able to explain $26.1 \%$ of the variability in the value of the insurance sub-sector company. There are still $73.9 \%$ of the influence of other variables that are not included in this research model.

$H_{5}$ result discussion. The regression coefficient of firm size is -0.082 with a significance of 0.514 . This means that firm size does not have a significant effect on firm value. This explains that companies with large sizes does not guarantee good asset management in increasing firm value (Endri, 2020). This finding is contradictive with signaling theory which states that the larger the size of a company, the greater of positive signal the company sends to the market. The results of this study in line with Li (2016), who examined financial companies listed on the Shanghai \& Shenzhen Stock Exchange, Prayoga (2013) examined the manufacture sector listed on the IDX for the period 2007-2011 and Farhan (2017) examined manufacture companies listed at Istanbul Stock Exchange for the period 2008-2013. The results of this study does not support Abdullah (2015) who examined public companies listed on the Malaysia Stock Exchange, Anton (2018) examined public companies listed on the Romanian Stock Exchange before the 2001-2007 financial crisis, \& Hao (2018) examined state insurance company in Ghana 2018.

$\mathrm{H}_{6}$ result discussion. The DER regression coefficient value is -0.266 with a significance of 0.038 . This means that DER has a significant negative effect on firm value. If the company's debt increases by one unit, it will decrease the company's value by 0.266 units. This explains that the higher the level of corporate debt, the lower of firm value is and in line with trade-off theory, since the level of debt of the insurance sub-sector companies is already high and has passed its optimal limit. As a result, when debt is increased, the value of the company will decrease because the tax benefits on debt are lower than the potential value of company bankruptcy for large debts. The average DER value of insurance companies 1.58 which is indicates that the company's debt is greater than shareholder equity. This finding is in line with research by Darmayanti (2018) who examined the manufacture sector listed on the Indonesia Stock Exchange for the period 2011-2015. Darmawan et. al (2020) who examined the manufacture sector listed on the Indonesia Stock Exchange for the period 2011-2015. This finding is not in line with Pratama (2016) who examined the telecommunications sub-sector listed on the Indonesia Stock Exchange for the period 2009-2013, Bertinetti (2013) examined 200 financial and non-financial companies listed on the STOXX® Europe Large 200 Index for the period 2002-2011, and Aditya (2017) examined the property \& construction sector listed on the Indonesia Stock Exchange for the period 2012-2014.

$\mathrm{H}_{7}$ result discussion. The regression coefficient of the effect of ROA on Tobin's $Q$ is 0.002 with a significance of 0.990. This means that ROA has no significant effect on firm value. This finding is contradictive with Tobin's $Q$ theory which states that firm profit can increase firm value. Tahir (2011) explains that the company's profit is not always fixed every year and the fluctuating trend of profitability of the insurance sub-sector during the 2015-2019 period causes profitability does not able to affect firm value. In addition, if the company's capital structure is mostly financed by debt, the company has an obligation to pay interest, which can reduce the company's ability to generate net income. This finding is in line with Lin (2016) who examined 105 insurance companies in the United States for the period 2000-2007, Farhan (2017) who examined manufacturing companies listed on the Istanbul Stock Exchange for the period 2008-2013, and Anton (2018) examined public companies listed on the Romanian Stock Exchange for the period 2001-2007. Meanwhile, this finding is not in line with Endri (2020) who examined the 
financial sector listed on the Indonesia Stock Exchange for the period 2013-2017, Rizqia (2013) who examined the manufacture sector listed on the Indonesia Stock Exchange for the period 2006-2011, Iswajuni (2018) who examined on the manufacture sector listed on the Indonesia Stock Exchange for the period 2010-2013.

$\mathrm{H}_{8}$ result discussion. The regression coefficient value of the effect of institutional ownership (INS) on firm value is -0.497 with a significance of 0.000 . This means that INS has a significant negative effect on firm value. When institutional share ownership increases by one unit, it will decrease the firm value by 0.497 units. This explains that when institutions own more shares in a company, the individual investors in the market have limited opportunities to own shares in the company. As a result, interest in owning the company's shares decreased. This falling interest causes the company's share price to fall. The stock price is a mirror of market value, when the stock price goes down, Tobin's $Q$ value will go down. The average shareholding value of the insurance sub-sector is $72 \%$ (above 50\%), indicating that institutional investors are the majority shareholders. These findings support the the strategic alignment hypothesis (McCardle, 2019) which explains that when institutional investors have great control in the company, it can influence or force management to make decisions according to their interests and ignore minority shareholdings. This condition is an unfavorable signal for non-institutional investors where they will reconsider their decision to invest. The results of this study are in line with the findings of Rahma (2014) who examined on the manufacture sector listed on the Indonesia Stock Exchange for the period 2009-2012 and Suteja (2009) who examined on the manufacture sector listed on the Indonesia Stock Exchange for the period 1994-2004. The result of this study is not in line with Ratnawati (2018) who examined the manufacturing sector listed on the Indonesia Stock Exchange for the period 2012-2014, Wimelda (2017) who examined 270 public companies listed on the Indonesia Stock Exchange for the period 2012-2014, and Purba (2019) who examined the manufacturing sector listed on the Indonesia Stock Exchange for the period 2013-2016.

H9 result discussion. The regression coefficient of the effect of ERM on firm value is 0.104 with a significance of 0.438 . This means that ERM has no significant effect on firm value. This is most likely because the market or investors think the company is implementing ERM just a formality. The result of this test is in line with the findings of Aditya (2017) who examined property \& construction companies listed on the IDX for the 2012-2014 period, Agustina (2016) who examined banking companies listed on the IDX for the 2011-2013 period, and Lin (2016) who examined on 105 insurance companies in the United States 2000-2007 period. This result is not in line with the findings of Bertinetti (2013) from Italy who examined european financial and non-financial companies listed on the STOXX® Europe Large 200 Index for the period 2002-2011, Husaini (2017) who examined on the nonfinancial sector listed on the Indonesia Stock Exchange for the 2010-2013 period, as well as Vergian (2019) who examined public companies listed on the JIS (Jakarta Islamic Index) for the period 2015-2017.

Result of Sobel test. The results show that ERM is not able to mediate the effect of firm size, leverage, profitability, and institutional ownership on firm value. The results of this test indicate that the company's ERM disclosure is still seen by investors just an effort to build an image (Michelon et al., 2015). ERM disclosure has not been able to increase investor confidence in risk management by the company so that it has not been able to increase firm value. The limited qualitative ERM disclosure is considered less relevant and it is difficult to compare the value between companies as a basis data for making investment decisions by investors (Skerci, 2013). However, the increased R square value in equation model-2 shows that the ERM variable is one of the determinants of the value of the insurance sub-sector company on the Indonesia Stock Exchange.

\section{Conclusion}

This study finds empirical evidence that firm size has a significant positive effect on ERM, DER and ROA has a significant negative effect on ERM, while institutional ownership has no effect on ERM. Furthermore, the results show that DER and institutional ownership have a significant negative effect on firm value, meanwhile company size, ROA, and ERM have no significant effect on firm value. ERM as an intervening variable is not able to mediate the influence of firm size, DER, ROA, and institutional ownership on firm value of insurance companies listed on the IDX in 2015-2019 period.

The ability of the model built in this study is relatively low. Further researches are advised to add other explanatory variables that affect ERM and firm value such as Earning Per Share, Auditor's Reputation, Company Growth, and Dividend Policy.

For investors who prioritize enterprise risk management (ERM), it is necessary to pay attention to company size. This study proves that company size has the greatest influence on the ERM in insurance company. The bigger the size of the company, the higher the openness of enterprise risk management. Meanwhile, investors who prioritize firm value to support their investment decisions are advised to pay particular attention to the company's share 
ownership. Share ownership by institutions has the greatest effect on firm value. The more institutions that own company shares, the lower the firm value is.

Future research that conduct using ERM as an intervening variable suggest to replacing the research object, like in banking companies, or multi-finance companies. Research can also be extended to all companies in the financial sector listed on the IDX or OJK.

The next research can use profitability variabel as measured by ROE as an intervening variable. Research by Hamidy et al (2015) finding ROE can indirectly mediate DER in increasing firm value. Further research can be carried out to determine the optimal point of use of debt, so the level of corporate debt can be found which shows that the tax benefits of using debt are as large as the cost of bankruptcy arising from the use of debt. This optimal level of debt can provide guideline for company managers in using debt as a source of corporate funding.

Insurance companies should reduce the use of debt so the firm value increases. In addition, management needs to control institutional share ownership, because the greater the ownership of shares by the institution the lower the firm value is. Moreover, insurance companies should continue to improve and increase the quality of their ERM disclosures, so the ERM disclosure as intervening variable can increases firm value.

\section{Acknowledgments}

The authors would like to thank the anonymous reviewers for constructive comments or suggestions on this paper.

\section{References}

Abdullah, M., Abdul, S. Z., Zaleha, A. S., Zakiah, M. M., \& Azlina, A. (2015). Risk Management Disclosure: A Study on The Effect of Voluntary Risk Management Disclosure Toward Firma Value. Journal of Applied Accounting Research, 16(3), 400-432. https://doi.org/10.1108/JAAR-10-2014-0106

Aditya, O., \& Prima, N. (2017). Penerapan Manajemen Risiko Perusahaan dan Nilai Perusahaan di Sektor Konstruksi dan Properti. Esensi: Journal Bisnis dan Manajemen, 7, 167-180. https://doi.org/10.15408/ess.v7i2.4981

Agustina, L., \& Niswah, B. (2016). The Relationship Between Enterprise Risk Management (ERM) And Firm Value Mediated Through the Financial Performance. Review of Integrative Business and Economics Research, $5(1), 128-138$.

Ahmed, N. Ahmed, Z., \& Ahmed, I. (2010). Determinants of Capital Structure: A Case of Life Insurance Sector of Pakistan. Europe Journal of Economics, Finance \& Administrative Sciences, 24, 7-12.

Al-Shammari, B. (2014). Kuwait Corporate Characteristic \& Level of Risk Disclosure: A Content Analysis Approach. Journal of Contemporary Issues in Business Research, 3(3), 128-153.

Anton, S. G. (2018). The Impact of Enterprise Risk Management on Firm Value: Empirical Evidence from Romanian Non-Financial Firms. Inzinerine Ekonomika-Engineering Economics, 29(2), 151-157. https://doi.org/10.5755/j01.ee.29.2.16426

Ardiansyah, La Ode Muhammad, \& Akhyar, A. M. (2014). Faktor-Faktor yang Mempengaruhi Luas Pengungka pan Enterprise Risk Management. Journal Ekonomi, Manajemen, dan Akuntansi, 23, 89-105.

Benyamin, I. A., \& Endri, E. (2019). Determinants of stock returns of building construction companies listed on the IDX Period 2012-2016. Scholars Journal of Economics, Business \& Management, 6(1), 39-47. https://doi.org/10.21276/sjebm.2019.6.1.6

Bertinetti, G. S., Elisa, C., \& Gloria, G. (2013). The Effect of The ERM Implementation on The Firm Value of European Firm. Working Paper Series 10, Department of Management, Università Ca' Foscari Venezia, 10, $01-22$.

Brigham \& Houston. (2014). Dasar-Dasar Manajemen Keuangan. Salemba Empat. Jakarta.

Butterfield, B. P. (2017). Traditional Risk Management vs Enterprise Risk Management: Which Approach Is the Best Choice for Your Company? Retrieved July 17, 2020, from https://www.mondaq.com/unitedstates.

COSO (Committee of Sponsoring Organizations of the Treadway Commission). (2004). Enterprise Risk Management Integrated Framework. Retrieved August 1, 2020, from http://www.coso.org/documents/erm.

Darmawan, A., Yudhistira, P. P., \& Yudhistira, P. A. (2020). Pengaruh Profitabilitas dan Leverage Terhadap Nilai Perusahaan dengan CSR sebagai variabel Moderasi dan Ukuran Perusahaan sebagai variabel kontrol. Journal Akuntansi dan Bisnis, 5(1), 83-92. https://doi.org/10.32502/jab.v5i1.2461

Darmayanti, F. S., \& Ika, U. W. (2018). Pengaruh Kepemilikan Manajerial, Kepemilikan Institusional, Kebijakan 
Utang Terhadap Nilai Perusahaan. Journal Manajemen \& Bisnis, 9(1) 1-20.

Dionne, G. (2013). Risk Management: History, Definition and Critique. Canada Research Chair in Risk Management, 1-34. http://dx.doi.org/10.2139/ssrn.2231635

Endri, \& Moch, F. (2020). Determinants of firm's value: Evidence from financial industry. Management Science Letters, 10, 111-120. https://doi.org/10.5267/j.msl.2019.8.011

Faisal, M. (2020). Karakteristrik CEO dan Enterprise Risk Management. Jurnal Riset Akuntansi \& Keuangan, 8(1), 109-120. https://doi.org/10.17509/jrak.v8i1.20741

Farhan, M., \& Özlem, S. (2017). Enterprise Risk Management and Its Effect on Firm Value in Turkey. Journal of Management Research, 9(1), 86-99. https://doi.org/10.5296/jmr.v9i1.10124

Farida, A. L., A. R., \& Siti, M. W. (2019). Determinant Variables of Enterprise Risk Management, Audit Opinions \& Firm value On Insurance Emitents Listed in Indonesia Stock Exchange. International Journal of Scientific \& Technology Research, 8(7), 288-293.

Fathimiyah, V. R., \& Zulfikar, dan Fara Fitriani. (2011). Pengaruh Struktur Kepemilikan Terhadap Risk Management Disclosure (Studi Survei Industri Perbankan Yang Listing Di Bursa Efek Indonesia Tahun 20082010). Skripsi. Universitas Sultan Ageng Tirtayasa.

Fauzia, M., \& Sakinah, R. D. S. (2020). Efek Kasus Jiwasraya, Banyak Investor Alihkan Portofolio ke Obligasi. Retrieved July 20, 2020, from https://money.kompas.com

Ghozali, Imam. (2013). Aplikasi Analisis Multivariate dengan Program IBM SPSS. Badan Penerbit Universitas Diponegoro. Semarang.

Hamidy, R. R. I., Gusti, B. W., \& Luh, G. S. A. (2015). Pengaruh Struktur Modal Terhadap Nilai Perusahaan dengan Profitabilitas Sebagai Variabel Intervening. E-Journal Ekonomi dan Bisnis Universitas Udayana, 4(10), 665-682.

Hao, Y. H. \& Linda, A. S. (2018). Enterprise Risk Management Adoption and Significant Positive Impact on Firm value, Case Study of SIC Insurance Company Ghana. Journal of Research in Business, Economics \& Management, 11(5), 2221-2228.

Harmono. (2009). Manajemen Keuangan Berbasis Balanced Scorecard (Pendekatan Teori, Kasus, dan Riset Bisnis). Bumi Aksara. Jakarta.

Hartono, J. (2000). Teori Portofolio dan Analisis Investasi. BPFE. Yogyakarta.

Hastuti, R. K. (2020). Kacau gagal bayar 5 asuransi ini bikin nasabah teriak. Retrieved March 24, 2021, from https://www.cnbcindonesia.com

Hoyt, R. E., and Liebenberg. (2011). The value of enterprise risk management. Journal of Risk and Insurance, 78(4), 795-822. https://doi.org/10.1111/j.1539-6975.2011.01413.x

Husaini, \& Saiful. (2017). Enterprise Risk Management, Corporate Governance \& Firm Value: Empirical Evidence from Indonesian Public Listed Companies. International Journal of Advances in Management and Economics, 6(6), 16-23.

Iswajuni, Soegeng Soetedjo, \& Arina, M. (2018). Pengaruh Enterprise Risk Management (ERM) Terhadap Nilai Perusahaan Pada Perusahaan Manufaktur yang terdaftar di BEI. Journal of Applied Managerial Accounting, 2(2), 147-153. https://doi.org/10.30871/jama.v2i2.942.

Jensen C, M., W.H. Meckling. (1976). Theory of The Firm, Managerial Behavior, Agency Cost, \& Ownership Structure. Journal of Financial Economics, 3, 305-360. https://doi.org/10.1016/0304-405X(76)90026-X.

Kasmir. (2015). Analisis Laporan Keuangan. Raja Grafindo Persada. Jakarta.

Kenton, Will. (2020). Economies of Scale. Retrieved Dec 25, 2020 from https://www.investopedia.com

Kumalasari, M., Subowo., \& Anisykurillah, I. (2014). Faktor-Faktor yang Berpengaruh Terhadap Luas Pengungkapan Manajemen Risiko. Accounting Analysis Journal, 3, 01-17. https://doi.org/10.15294/aaj.v3i1.3896.

Lestari, Sri Rahayu. (2017). Pengaruh Dewan Direksi, Komisaris Independen, Kepemilikan Manajerial, dan Kepemilikan Institusional Terhadap Kinerja Perusahaan dengan ERM sebagai Intervening. JOM Fekon, 4(1), 3081-3094.

Li, Qiuying, Wu, Y., Ojiako, dkk. (2014). Enterprise Risk Management \& Firm Value Within China's Insurance 
Industry. AOSIS Open Journals, 14(1), 1-10. http://dx.doi.org/10.4102/ac.v14i1.198.

Li, Z. W., \& Wang, Y. Ch. dkk. (2016). Relationship Between Initiative Risk Management \& Firm Value: Evidence From Chinese Financial Listed Company. Journal Applied Economics, 48(8), 658-668. https://doi.org/10.1080/00036846.2015.1085639.

Lin, Yijia, Min-Ming Wen, Jifeng Yu. (2016). Enterprise Risk Management, Strategic Antecedents, Risk Integration \& Performance. North American Actuarial Journal, 16(1), 1-28. https://doi.org/10.2139/ssrn.1629341.

Lukviarman, N. (2008). Dasar-Dasar Manajemen Keuangan. Andalas University. Padang.

Malik, H. (2011). Determinants of insurance company profitability: an analysis of insurance sector of Pakistan. Academic Research International, 1(3), 315-321.

Mamduh M. H. (2014). Manajemen Keuangan. Edisi Kedua, BPFE. Yogyakarta.

Marhaeni, T., \& Yanto, H. (2015). Determinan Pengungkapan Enterprise Risk Management (ERM) pada Perusahaan Manufaktur. Accounting Analysis Journal, 4(4), 1-22. https://doi.org/10.15294/aaj.v4i4.9113

McShane, K. M., Anil. N., \& Elzotbek, R. (2011). Does Enterprise Risk Management Increase Firm Value. Journal of Accounting Auditing \& Finance, 26(4), 641-658. https://doi.org/10.1177/0148558X11409160

Michelon, G., Pilonato, S., \& Ricceri, F. (2015). CSR reporting practices and the quality of disclosure: An empirical analysis. Critical Perspectives on Accounting, 33, 59-78. https://doi.org/10.1016/j.cpa.2014.10.003

Modigliani, F., \& Miller, M. H. (1958). The Cost of Capital, Corporate Finance, and the Theory of Investment. The American Economic Review, 48(3), 261-297.

Murtini, U. (2018). Pengaruh Enterprise Risk Management terhadap Nilai Perusahaan dengan Variabel Kontrol Ukuran Perusahaan dan DER. Journal Bisnis, Manajemen \& Perbankan, 9(1), 1-94. https://doi.org/10.21070JBMP.V4i1.

Nugroho, A. S., Nursyamsyi, M., \& Adinda, P. (2020). Dua Skema Penyelamatan Jiwasraya. Retrieved May 12, 2020, from 2020, https://www.republika.co.id

Nuraina, E. (2012). Pengaruh Kepemilikan Institusional dan Ukuran Perusahaan terhadap Kebijakan Utang dan Nilai Perusahaan. Jurnal Bisnis \& Ekonomi, 12(2), 110-125. http://dx.doi.org/10.26740/jaj.v4n1.p51-70.

Onder, S., \& Ergin, H. (2012). Determiners of Enterprise Risk Management applications in turkey: An empirical study with logistic regression model on the companies included in Istanbul Stock Exchange. BEH - Business \& Economic Horozons, 7(1), 19-26.

Otoritas Jasa Keuangan/ OJK RI (2015). Retrieved July 11, 2020, from https://www.ojk.go.id/id/regulasi/Doc

Pamungkas, A. (2019). Pengaruh Penerapan ERM terhadap Nilai Perusahaan: Studi Empiris pada Perusahaan Manufaktur yang Terdaftar di BEI. Journal Akuntansi Maranatha, 11(1), 12-21. https://doi.org/10.28932/jam.v11i1.1539

Pratama, I. G. B. A., \& I Gusti, B. W. (2016). Pengaruh Ukuran Perusahaan dan Leverage terhadap Nilai Perusahaan dengan Profitabilitas sebagai Variabel Mediasi. E-Journal Manajemen Universitas Udayana, 5(2), 1338-1367.

Prayoga, E. B., \& Luciana, S. A. (2013). Pengaruh Struktur Kepemilikan dan Ukuran Perusahaan terhadap Manajemen Risiko. Journal Akuntansi \& Keuangan, 4, 1-19.

Pristianingrum, N. Y. S., \& Agung, B. S. (2018). Effect of Firm Size, Leverage, and Instituional Ownership on Disclosure of ERM. International Journal of New Technology and Research, 4(8), 08-11.

Purba, N. M. Br., \& Syahril, E. (2019). Pengaruh Kepemilikan Manajerial \& Kepemilikan Institusional terhadap Nilai Perusahaan. Jurnal Akuntansi Barelan, 3(2), 64-74. https://doi.org/10.33884/jab.v3i2.1013

Rachmawati, D., \& Dahlia, B. P. (2015). Pengaruh Profitabilitas, Leverage, dan Ukuran Perusahaan terhadap Nilai Perusahaan. EQUITY Journal, 18(1), 01-18. http://dx.doi.org/10.34209/equ.v18i1.456

Rahma, A. (2014). Pengaruh Kepemilikan Manajerial, Kepemilikan Institusional, \& Ukuran Perusahaan terhadap Keputusan Pendanaan dan Nilai Perusahaan. Jurnal Bisnis Strategi, 23(2), 45-69.

Ratnawati, V., \& Azhari, dkk. (2018). The Impact of Institutional Ownership \& a Firm Size on Firm Value Tax Avoidance as a Moderating Variabel. Journal of Finance \& Banking Review, 3(1), 1-8.

Ross, S. A. (1970). The Arbitrage Theory of Capital Asset Pricing. Journal of Economic Theory. United States: 
Academic Press Inc. Burlington. MA, 1803-4252

Rujiin, Choiru. \& Sukirman (2020). The Effect of Firm LEV, Leverage, Profitability, Ownership Structure, and Firm Age on ERM. Accounting Analysis Journal, 8(2), 81-82. https://doi.org/10.15294/aaj.v9i2.33025

Salvatore, D. (2005). Ekonomi Manajerial dalam Perekonomian Global. Edisi 5. Jakarta: Salemba Empat.

Saputro, Candra Dwi \& Bambang Suryono. (2014). Pengaruh Struktur Kepemilikan, Leverage, \& Firm Size terhadap Pengungkapan Manajemen Risiko. Journal Ilmu \& Riset Akuntansi, 3, 231-243.

Sari, F. J. (2013). Implementasi ERM Pada Perusahaan Manufaktur di Indonesia. Accounting Analysis Journal, 2, 164-170. https://doi.org/10.15294/aaj.v2i2.1440

Saskara, I. P. W., \& I Gusti, A. N. B. (2018). Pengaruh Leverage dan Profitabilitas pada Pengungkapan Manajemen Risiko. E-Journal Akuntansi Universitas Udayana, 24, 1991-2022. https://doi.org/10.24843/EJA.2018.v24.i03.p13

Sianturi, M. W. E. (2015). Pengaruh Kinerja Keuangan terhadap Nilai Perusahaan Manufaktur Sektor Konsumsi di BEI. E-journal Ilmu Administrasi Bisnis, 3(32), 282-296.

Sithipolvanichgul, J. (2018). The Determinant of ERM Implementation: Evidence in Thailand and Malaysia. Thammasat Review, 21(1), 1-25.

Skerci, N. (2013). Does Enterprise Risk Management Create Value for Firms? Evidence from Nordic Countries. Ph.D thesis: School of Economics and Management Lund University. Sweden.

Sudana, I. M. (2011). Manajemen Keuangan Perusahaan Teori dan Praktek. Erlangga. Jakarta.

Sulistyaningsih \& Barbara, G. (2016). Analisis Faktor-Faktor yang Mempengaruhi Risk Management Disclosure. Riset Akuntansi \& Keuangan Indonesia, 1, 1-11. https://doi.org/10.23917/reaksi.v1i1.1973.

Suteja. Jaja \& Wiston Manihuruk. (2009). Pengaruh Struktur Modal, Kepemilikan, dan Faktor Eksternal pada Penentuan Nilai Perusahaan. Journal Trikonomika, 8(2). https://doi.org/10.13140/RG.2.2.12355.22565.

Syifa, L. (2013). Determinan Pengungkapan ERM pada Perusahaan Manufaktur di Indonesia. Accounting Analysis Journal, 2, 287-294. https://doi.org/10.15294/aaj.v2i3.2515.

Tahir, I. M., \& Ahmad, R. R. (2011). The Relationship Between Enterprise Risk Management (Erm) and Firm Value: Evidence from Malaysian Public Listed Companies. International Journal of Economics \& Management Sciences, 1(2), 32-41.

Taleb, N. N. (2007). The Black Swan, Rahasia terjadinya Peristiwa Peristiwa Langka yang Tak Terduga. Gramedia Pustaka Utama. Jakarta.

Tessema, A. M. (2016). Mandatory hedging disclosure and risk management activities: the impact of product market competition. International Journal of Accounting \& Information Management, 24(1), 82-98.

Tobin, Prof. James. (1967). Tobin's Q Ratio as An Indicator of the valuation of the company. Journal of Financial Economics, 3(3), 287-298.

Trisdia, M. K., \& Badera, I. D. N. (2018). Institusional Ownership Capability in Moderated Disclosure Effect of ERM, Intellectual Capital, \& CSR on Firm Valu. Russian Journal of Agricultural \& Socio-Economic Sciences, 6(78), 313-321. https://doi.org/10.18551/rjoas.2018-06.36

Vergian, F., \& Azib. (2019). Pengaruh Mekanisme Corporate Governance, ERM, IC Disclosure terhadap Nilai Perusahaan Terdaftar di Jakarta Islamic Index. Prosiding Management, 5(1), 337-344.

Wareza, M. (2020). Geger Jiwasraya, Begini Dampak ke Industri Asuransi Jiwa. Retrieved September 9, 2020, from https://www.cnbcindonesia.com

Wimelda, L., \& Sylvia, V. S. (2017). The Effect of Financial Institution Ownership on Firm Value. Journal of Corporate Ownership \& Control, 14(2), 114-122. https://doi.org/10.22495/cocv14i2art11.

\section{Copyrights}

Copyright for this article is retained by the author(s), with first publication rights granted to the journal.

This is an open-access article distributed under the terms and conditions of the Creative Commons Attribution license (http://creativecommons.org/licenses/by/4.0/). 